\title{
Modeling the competencies of a top manager as part of a management team
}

\author{
D. S. Korolov \\ Volodymyr Dahl East Ukrainian National University, Severodonetsk, Ukraine \\ Corresponding author. E-mail: Deniskorolov@ukr.net
}

Paper received 11.03.21; Accepted for publication 10.04.21.

\begin{abstract}
https://doi.org/10.31174/SEND-HS2021-254IX46-08
\end{abstract}
\begin{abstract}
The article substantiates that special attention should be paid to the level of development of competencies, managers, contributing to the achievement of team results when assessing the competencies of team members in the top management of a company. The adapted "20 faces" competency framework of top managers of the company was clarified by assigning different weights to competencies, whose high level of development is a prerequisite for effective activity of a manager as part of a team. An expert survey of specialists was conducted, according to the results of which the importance of competencies aimed at obtaining a team result, wellcoordinated work and obtaining a synergistic effect from the team cooperation of the company's top managers was confirmed. The aggregate indicator of the level of development of top managers' competencies was clarified by taking into account the weighting factors, which were determined as a result of an expert survey.
\end{abstract}

Keywords: competency-based approach, top manager, competency framework, expert assessment, weight coefficient, aggregate indicator.

Introductory paragraph. Compliance with the competency framework for a specific job position in a specific company is a prerequisite for the effective performance of employees' professional duties. The degree of inconsistency of the employee with the competency framework allows the company's management to draw conclusions about the advisability of holding this position or the need to develop specific competencies through training, skills upgrade, gaining professional experience, etc. Where the study examines the competencies of top managers, the compliance of employees with the competency framework of the top-level management position directly affects not only the quality of performance of direct professional duties, but also affects the efficiency of the company as a whole. Because of these reasons the competency framework of the company's top manager should be comprehensive, it should take into account the specifics of activities in senior management positions and create an opportunity for a reasonable assessment of the employee's compliance with the requirements of a specific position and corporate values.

Succinct overview of publications for the topic. On a gross scale, a competency framework is understood as a set of individual competencies that an employee must possess in order to perform functions in a specific position in a specific organization. A competency framework contains various knowledge, abilities, skills, personal characteristics, the main requirement for which is the ability to describe them through a system of behavior indicators [1]. The competency framework helps to clearly define the professional and behavioral requirements for an employee, depending on his managerial level, profession, position and tasks [2]. Since different competencies have different significance for ensuring the successful professional activity of an employee depending on the position, individual competencies can be assigned a different weight in the total set with its total value of $100 \%$, or a unit [1, p. 71]. In order to increase the framework efficiency, individual competencies that make up its composition are combined into clusters (blocks, groups) based on kinship [2].
In the selection process for vacant positions, companies began to use the model of D. McClelland [3], which was proposed in the framework of the motivational theory of needs, and the tool for modeling the managerial competence of L. Spencer and S. Spencer [4]. As well as, the competency framework of managers "20 faces" of the ADC company has become widespread [5], which contains 20 competencies important for the activity of a manager, which are divided into 5 groups based on similarity: management skills, internal motivation, decision-making skills, personal qualities, interpersonal interaction skills. The author in his work [6] provided recommendations for clarifying structure and elemental composition in order to adapt the "20 faces" framework to assessing the competencies of top managers. Based on the clarifications provided, a competency framework for top managers of the company was proposed, which provides for the allocation of 6 groups of competencies - K1 "Personal qualities", K2 "Internal motivation", K3 "Management skills", K4 "Decision-making skills", K5 "Interpersonal interaction skills", K6 "Professional competencies". Each of the competency groups consists of 4 competencies, the level of development of which makes it possible to assess the compliance of the top-level manager with the requirements of the position held. The set of competencies of "20 faces" adapted framework (both in the sense of the selected groups and their specific components) is formed in such a way that they provide a fundamental assessment of the degree of conformity of an employee to the position held at the top level of company management. Anyway, taking into account the task of forming teams in the top management of the company, it would be advisable to introduce further changes in the "20 faces" framework in such a way as to offer the most effective tool for assessing the effectiveness of cooperation between top managers in the team.

The purpose of the article is to develop an approach to modeling and assessing the competencies of top managers as part of a management team

Materials and methods. Analysis and synthesis methods are used to systematize the competence requirements 
of the company's top managers as part of a team; statistical analysis method - to verify the results of expert assessment of the significance of top managers competencies; mathematical modeling method - to formalize the aggregate indicator of the level of competence development of company top managers as part of the management team.

Results. The rationale for developing an approach to assessing the competence of top-level managers is understanding the key difference between individual professional activities and the inclusion of a top manager in the management team. In particular, teamwork is impossible without the observance by its participants of common values, cooperation and partnership, a high level of cohesion and collective responsibility for the results. Members of the management team must act together, coordinate their work and focus on achieving a common goal. Therefore, we believe that the emphasis in assessing the competencies of team members in the top management of the company should not be to determine the level of their compliance with their positions, since the fact that managers belong to the top management level is already evidence of their high professionalism and career success. In this case, attention should be focused on assessing the level of the managers competencies development that contribute to the achievement of a team result even due to the neglect of individual achievements, and are in the sphere of not so much professional as personal competencies. In the furtherance of this goal, it is proposed to introduce additional clarifications in the "20 faces" adapted model of company top managers competencies by assigning different weights to competencies, a high level of development of which is a prerequisite for effective activity of a manager as part of a team.

In order to identify the most significant top managers' competencies from the point of view of ensuring the effectiveness of the management team, 30 representatives of the highest management level of domestic companies of various forms of ownership, scope and scale of activity were interviewed. The purpose of the interview was to form a competency model for a top manager as part of a management team based on the ranking of groups of competencies and individual competencies in their composition in terms of their significance for ensuring the effectiveness of teamwork. The essence of the interview was the provision by experts, in the role of which were top-level managers, assessments of the competency groups (stage 1 of the procedure) and competencies within each of the groups of the competency model (stage 2 of the procedure), which indicate the significance of a specific group of competencies / specific competence of the top manager to ensure the effective functioning of the management team. The assessment of the competencies groups significance, according to their number, was carried out in the range from 1 (the minimum assessment, the group of competencies is the least important) to 6 (the maximum assessment, the group of competencies is the most important). The assessment of the significance of specific competencies in each of the groups was provided in the range from 1 (minimum assessment, competence is the least important) to 4 (maximum assessment, competence is the most important).

At the first stage, the assessment procedure was subject to the significance of the competence groups of top managers to ensure the effectiveness of the management team, the results of which are presented in Table 1. Based on the calculation of statistical values, the obtained results were verified and it was confirmed that the deviations in the values of expert estimates correspond to the normal distribution law, which allows us to consider the results of the expert evaluation procedure as mutually consistent.

The results of the expert assessment create the basis for ranking the groups of competencies according to their significance from the point of view of ensuring the effectiveness of the team of company top managers, and assigning them weight coefficients (Table 2). The calculation of the weight coefficient for each of the groups of competencies is carried out according to the formula:

$$
\alpha_{i}=\frac{Z_{i}}{\sum_{i=1}^{k} Z_{i}},
$$

where $\alpha_{i}-$ weight coefficient of a group of competencies in the general set; $Z_{i}$ - the number of points received by the competency group; $k$-number of competency groups.

The assignment of significance ranks to competency groups is carried out in descending order of weight coefficients in the general set - from 1 (maximum significance rank) to 6 (minimum significance rank).

Table 1. Results of experts' assessment of the significance of competency groups of top managers in the management team

\begin{tabular}{|c|c|c|c|c|c|c|c|}
\hline \multirow[t]{2}{*}{ Competence group code } & \multicolumn{6}{|c|}{$\begin{array}{l}\text { The number of experts who provided an appropriate assessment of the significance of a } \\
\text { group of competencies }(1-\min , 6-\max )\end{array}$} & \multirow[t]{2}{*}{$\begin{array}{l}\text { Total number } \\
\text { of experts }\end{array}$} \\
\hline & 1 & 2 & 3 & 4 & 5 & 6 & \\
\hline \multicolumn{8}{|c|}{ "Personal qualities" } \\
\hline K1 & 8 & 10 & 5 & 4 & 2 & 1 & 30 \\
\hline \multicolumn{8}{|c|}{ "Internal motivation" } \\
\hline $\mathbf{K 2}$ & 12 & 7 & 5 & 3 & 2 & 1 & 30 \\
\hline \multicolumn{8}{|c|}{ "Management skills" } \\
\hline K3 & 5 & 6 & 9 & 5 & 3 & 2 & 30 \\
\hline \multicolumn{8}{|c|}{ "Decision-making skills" } \\
\hline K4 & 3 & 3 & 5 & 8 & 6 & 5 & 30 \\
\hline \multicolumn{8}{|c|}{ "Interpersonal interaction skills" } \\
\hline $\mathbf{K 5}$ & 0 & 1 & 3 & 4 & 6 & 16 & 30 \\
\hline \multicolumn{8}{|c|}{ "Professional competencies" } \\
\hline К6 & 2 & 3 & 3 & 6 & 11 & 5 & 30 \\
\hline
\end{tabular}


Table 2. The results of ranking the competency groups of top managers in the management team by significance

\begin{tabular}{|l|c|c|c|c|c|c|c|}
\hline \multirow{2}{*}{ Significance factors } & \multicolumn{9}{|c|}{ Competency groups } & K4 & K5 & K6 \\
\cline { 2 - 8 } & K1 & K2 & K3 & 14 & 25 & 20 \\
\hline Weight coefficient $\alpha_{i}$ & 12 & 11 & 14 & 18 & 1 & 2 \\
\hline Significance rank & 5 & 6 & 4 & 3 & 1 & \\
\hline
\end{tabular}

It is necessary to analyze the results of the expert survey in terms of assessing the importance of the K1-K6 competency groups in ensuring the effectiveness of the team of company top managers.

It should come as no surprise that the maximum (first) rank of significance as a result of summarizing the assessments of experts was obtained by the group of competencies K5 "Interpersonal interaction skills" (weight coefficient $-25 \%$ ), which was given the maximum assessment by more than half of the experts (16 out of 30 people). It is the manager's possession of the competencies of the relevant group (which includes, among other things, the competence K54 "Teamwork skills") that determines his ability to neglect individual interests and needs to ensure the effectiveness of team work. Possession of this group competencies is of particular importance for top-level managers, since, by default, representatives of the company's top management are highly qualified and knowledgeable employees, have a number of personal and professional achievements, have personalized knowledge and experience, which can lead to unwillingness to listen to other people's opinions and rejection of criticism. Without the desire of team members for mutual understanding, loyalty to opponents and the ability to sacrifice their own ambitions in favor of the overall result, the effective functioning of the top managers team is impossible, which causes the highest rank of competence of the "Interpersonal interaction skills" group. It should be noted that several experts assigned the maximum score (and, accordingly, the maximum significance rank) to other groups of competencies. Such assessments indicate an understanding of the significance of both managerial and professional skills to ensure the effectiveness of the company's top management team.

The second rank of significance according to the results of the expert assessment was given to the group of competencies K6 "Professional competences" (weight coefficient - 20\%), which was given the corresponding assessment by 12 out of 30 experts. This result confirms the understanding of the need for team members to possess professional skills to ensure a synergistic effect of a team of top managers as a result of a combination of professional competencies of various profiles. Although it should be noted that there is no absolute agreement between experts regarding the significance of professional competencies in ensuring a team result - a sufficiently large number of survey participants assigned this group of competencies the third, fourth, fifth and even sixth (last) significance rank.

Group K4 "Decision-making skills" received the third place in importance among the groups of competencies (weight coefficient - 18\%). This group includes competencies that assess the ability of a manager to structurally analyze problems (K41), collect and process information (K42), commercial thinking (K43) and its consistency (K44). Obviously, the possession of these competencies can be considered as a prerequisite for the effective activity of a manager, regardless of whether it is of an individual or team nature. This fact can explain the rather high (3rd) rank of significance, which the group of competencies K4 "Decision-making skills" received according to expert assessments.

The fourth rank of significance was assigned by the majority of its experts ( 9 people) to the competence group K3 "Management skills" (weight coefficient - 14\%). In this case, we can also talk about the relative, and not the absolute majority of specialists who adhere to this opinion, since a fairly significant number of experts consider manager skills as competencies of the third, fifth and sixth ranks of significance from the point of view of ensuring the effectiveness of the team. In our opinion, such a significant difference in assessments can be explained by the doubtful understanding of the role of management skills of team members precisely in the case of their belonging to the top management of the company. Namely, in the case of creating a team, which includes representatives of different levels of management, it can reasonably be considered that the key is the role of competencies associated with planning joint activities (K31), delegation of authority (K32), development of subordinates (K33) and effective leadership ( K34). If we are talking about a team of top managers, all members of which belong to the top management of the company, it is not the ability to manage subordinates that is of great importance, but, on the contrary, the understanding of the same (high) status of the team members, and the ability to make compromises to achieve a common result.

Finally, the two lowest ranks (fifth and sixth) according to the results of the expert assessment were received by the groups of competencies K1 "Personal qualities" and K2 "Internal motivation". The weight coefficients of these groups of competencies in terms of ensuring the performance of the top management team turned out to be almost the same $-12 \%$ and $11 \%$, respectively. The corresponding results (both in terms of the similarity of assessments and the low rankings obtained) can be explained by the similarity of these groups of competencies in essence and their focus on obtaining an individual result due to their own system of motivators, the development of personal qualities and professional growth. The priority in terms of the obtained rank of the $\mathrm{K} 1$ group is obviously due to the presence in this group of personal competencies that are important for teamwork - first of all, stress resistance (K11) and adaptability (K12).

Ranking of competency groups and assigning weight coefficients to them is the result of the first stage of the expert assessment procedure in order to form a competency model for a top manager as part of a management team. At the second stage, the assessment procedure from the point of view of importance for ensuring the effective functioning of the team is subject to individual competencies within each of the 6 competency groups of the "20 
faces" adapted framework. The assessment of the importance of specific competencies in each of the groups was provided in the range from 1 (minimum assessment, the least importance) to 4 (maximum assessment, the most importance). The results of experts' assessment of the significance of individual competencies of top managers in the management team are presented in Table 3.

In equivalent to the ranking of competency groups, the ranks of the importance of individual competencies can be determined from the point of view of ensuring the effectiveness of the team of top managers of the company, and weight coefficients can be assigned to them (Table 4). The assignment of significance ranks to competencies within the corresponding groups is carried out in descending order of weight coefficients in the general set - from 1 (maximum significance rank) to 4 (minimum significance rank). A brief analysis of the results of the expert survey should be carried out in terms of assessing the importance of individual competencies in ensuring the effectiveness of the team of top managers.

Competencies of the K1 "Personal qualities" group. The maximum (first) rank of significance as a result of summarizing the assessments of experts was obtained by the competence K11 "Stress resistance" (weight coefficient $-31 \%$ ), which was given the highest rating by 13 out of 30 experts. Further, in descending order of importance, are the competences K12 "Adaptability", K13 "Responsibility and organization" and K14 "Positive thinking" (respectively, 27\%, 24\% and 18\%). The assignment by experts of the maximum rank of competence K11 can be explained by the importance of emotional self-control in conflict situations that can arise in the management team when solving common problems. The same considerations can explain the assignment of the second most important rank of significance to the competence K12 "Adaptability".

Competencies of the K2 "Internal motivation" group. The first rank of significance from the point of view of ensuring the effectiveness of the team of top managers was given to the K21 "Initiative" competency (weight coefficient - 28\%), although most experts assigned the highest rating to the K23 "Focus on long-term results" competency (weight coefficient - 27\%). In any case, both of these competencies are more important for wellcoordinated teamwork than K22 "Orientation to incentives and motivators" and K24 "Development of personal skills and professional growth" (weight coefficient - 23\% and $22 \%$, respectively), which are focused primarily on self-improvement and personal achievements of a manager.

Table 3. Results of experts' assessment of the significance of individual competencies of top managers in the management team

\begin{tabular}{|c|c|c|c|c|c|c|}
\hline \multirow[t]{2}{*}{ 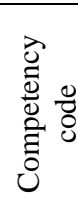 } & \multirow[t]{2}{*}{ Competency name } & \multicolumn{4}{|c|}{$\begin{array}{l}\text { The number of experts } \\
\text { who gave an appropriate } \\
\text { assessment of the signifi- } \\
\text { cance of competence } \\
(1-\text { min, } 4-\max )\end{array}$} & \multirow[t]{2}{*}{ 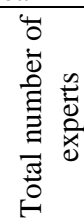 } \\
\hline & & 1 & 2 & 3 & 4 & \\
\hline \multicolumn{7}{|c|}{ Competencies of the K1 "Personal qualities" group } \\
\hline K11 & Stress resistance & 3 & 5 & 9 & 13 & 30 \\
\hline K12 & Adaptability & 5 & 7 & 10 & 8 & 30 \\
\hline K13 & Responsibility and organization & 8 & 9 & 7 & 6 & 30 \\
\hline K14 & Positive thinking & 14 & 9 & 4 & 3 & 30 \\
\hline \multicolumn{7}{|c|}{ Competencies of the K2 "Internal motivation" group } \\
\hline K21 & Initiative & 5 & 6 & 10 & 9 & 30 \\
\hline $\mathbf{K 2 2}$ & Orientation to incentives and motivators & 8 & 11 & 6 & 5 & 30 \\
\hline $\mathbf{K 2 3}$ & Focus on long-term results & 6 & 6 & 8 & 10 & 30 \\
\hline $\mathbf{K 2 4}$ & Development of personal skills and professional growth & 11 & 7 & 6 & 6 & 30 \\
\hline \multicolumn{7}{|c|}{ Competencies of the K3 "Management skills" group } \\
\hline K31 & Planning and organization of activities & 4 & 6 & 7 & 13 & 30 \\
\hline $\mathbf{K 3 2}$ & Delegation of powers and distribution of responsibilities & 6 & 8 & 9 & 7 & 30 \\
\hline K33 & Development of subordinates in accordance with the goals of the company & 7 & 7 & 9 & 7 & 30 \\
\hline K34 & Effective leadership & 13 & 9 & 5 & 3 & 30 \\
\hline \multicolumn{7}{|c|}{ Competencies of the K4 "Decision-making skills" group } \\
\hline K41 & Structural analysis of problems & 6 & 6 & 7 & 11 & 30 \\
\hline K42 & Collection and processing of relevant information & 7 & 6 & 6 & 11 & 30 \\
\hline K43 & Commercial thinking (profit orientation) & 9 & 10 & 8 & 3 & 30 \\
\hline K44 & Systematic thinking & 8 & 8 & 9 & 5 & 30 \\
\hline \multicolumn{7}{|c|}{ Competencies of the K5 "Interpersonal interaction skills" group } \\
\hline K51 & Empathy (interpersonal understanding) & 12 & 14 & 3 & 1 & 30 \\
\hline $\mathbf{K 5 2}$ & Ability for persuasive communication & 2 & 4 & 18 & 6 & 30 \\
\hline $\mathbf{K 5 3}$ & Creation of a favorable socio-psychological climate & 16 & 11 & 2 & 1 & 30 \\
\hline K54 & Teamwork skills & 0 & 1 & 7 & 22 & 30 \\
\hline \multicolumn{7}{|c|}{ Competencies of the K6 "Professional competencies" group } \\
\hline K61 & Compliance with professional education and experience of the position & 2 & 2 & 8 & 18 & 30 \\
\hline K62 & Ability to use professional knowledge in the company's activities & 7 & 9 & 10 & 4 & 30 \\
\hline K63 & Ability to transfer knowledge (professional mentoring) & 10 & 11 & 6 & 3 & 30 \\
\hline K64 & Attitude towards professional qualifications and their effectiveness & 11 & 8 & 6 & 5 & 30 \\
\hline
\end{tabular}

Source: compiled by the author based on [7, p. 343-344]

Competencies of the K3 "Management skills" group. The most significant as a result of the expert assessment 
in this group was the competence K31 "Planning and organization of activities" (weight coefficient - 30\%). Experts consider competences K32 "Delegation of powers and distribution of responsibilities" and K33 "Development of subordinates in accordance with the goals of the company" as practically equally important from the point of view of ensuring the team result (significance is $26 \%$ and $25 \%$, respectively). The assignment of the minimum rank of significance to the competence K34 "Effective leadership" (weight coefficient - 19\%) is due to the inexpediency of striving for leadership and demonstrating the relevant qualities in the team of top managers as people of a priori high status.

Competencies of the K4 "Decision-making skills" group. The weight coefficients of the competencies of this group in the general set were distributed quite evenly from the maximum value of $28 \%$ (competence K41 "Structural analysis of problems") to the minimum $22 \%$ (competency K43 "Commercial thinking"). The competence K42 "Collection and processing of relevant information" also has a fairly high weight coefficient at the level of $26 \%$, which, according to experts, has the second rank of significance. This distribution of weight coeffi- cients indicates the importance of analytical skills and skills in working with large amounts of information to ensure the effectiveness of the team of top managers of the company.

Competencies of the K5 "Interpersonal interaction skills" group. It is worth reminding that this group of competencies, based on the results of an expert assessment, received the first rank of significance among other groups with a correspondingly maximum weight coefficient at the level of $24 \%$, which is explained by the decisive role of interpersonal interaction skills in achieving the goals of teamwork. It is predictable that the first rank of significance within this group has competence K54 "Teamwork skills" with an extremely high weight coefficient of $37 \%$. Also, a fairly high weight coefficient at the level of $29 \%$ was assigned to the K52 competence "Ability for persuasive communication", which is certainly important for achieving mutual understanding between team members. The weight coefficients of the last two competencies in this group turned out to be quite low, amounting to $18 \%$ (competence K51 "Empathy") and $16 \%$ (K53 "Creating a favorable socio-psychological climate").

Table 4. Results of ranking the competencies of top managers in the management team by significance

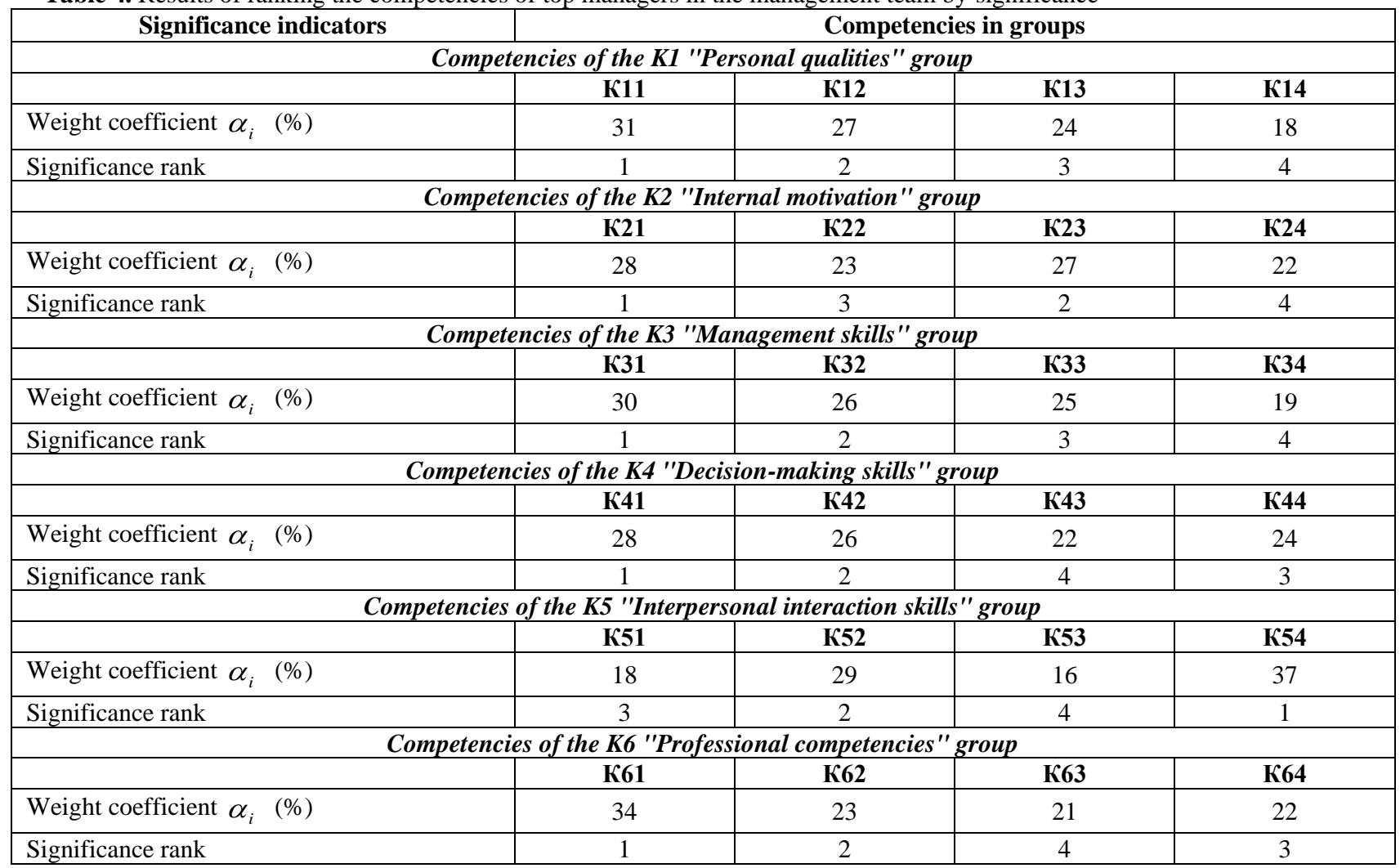

Source: compiled by the author

Competencies of the K6 "Professional competencies" group. Finally, by analyzing the values of the weight coefficients of competencies in this last group, we can attest to the prevalence of the significance of one competence over others. In particular, the competence K61 "Compliance with professional education and experience of the position held" (weight coefficient 34\%) received a great advantage, which confirms the importance of the correspondence of the knowledge of the top manager to his high status in the company management system. The weight coefficients of other competencies in this group in the general set do not differ significantly among themselves, and are, respectively, 23\% (K62 "Ability to use professional knowledge in the company's activities"), 22\% (K64 "Attitude towards professional qualifications and their effectiveness") and 21\% (K63 "Ability to transfer knowledge, or professional mentoring").

Summing up the analysis of the importance of individual competencies and groups of competencies as part of "20 faces" adapted framework from the point of view of 
ensuring the effectiveness of the team of top managers of the company, we can confirm the importance of competencies aimed at obtaining a team result, well-coordinated work and obtaining a synergistic effect from cooperation of managers.

The outlined approach to modeling competencies creates an opportunity for practical assessment of the competence-based compliance of top managers with the requirements for members of the management team. It ought to be noted that the advantage of the proposed approach is the introduction of weight coefficients for individual competencies and their groups, taking into account the importance of ensuring the effective functioning of top managers team. According to this criterion, on the results of the expert assessment procedure, the maximum significance ranks and high weight coefficients were obtained by competencies that reflect the manager's ability to coordinate teamwork, understanding the priority of the overall result over the individual one and the possibility of adhering to a compromise line of behavior in a team of employees of the same high status.

The recognition by experts of varying degrees of the contribution of individual competencies and their groups to ensuring the effectiveness of the team of top managers creates grounds for clarifying the aggregate indicator of the level of development of top managers competencies
[6, p. 44] by taking into account the weight coefficients that were determined as a result of an expert assessment:

$$
I_{K}=\left[\frac{1}{N} \sum_{j=1}^{N} y_{j} \frac{1}{M_{j}} \sum_{i=1}^{M_{j}} x_{i j} k_{i j}\right] * 100 \%,
$$

where $I_{K}$ - aggregate indicator of the level of competence development of top managers of the company as part of the management team; $N$-number of competency groups $(N=6) ; M_{j}$ - number of competencies in the $j$-th group $\left(M_{j}=4\right) ; k_{i j}$-assessment of the $i$-th competence in the $j$-th group $\left(k_{i j}=0, \ldots, 4\right) ; x_{i}$ - the weight coefficient of the $i$-th competence in the $j$-th group; $y_{j}$-the weight coefficient of the $j$-th group of competencies.

Conclusions. The proposed approach to modeling competencies created an opportunity for practical assessment of the competence-based compliance of top managers with the requirements for members of the management team. The methodology correction for calculating the aggregate indicator of the level of development of competencies will make it possible to more objectively assess the competence of a top manager as a member of the management team due to the presence of higher weight coefficients of competencies and their groups, which are the most significant from the point of view of ensuring the team result from the cooperation of the company top-level officials.

\section{LITERATURE}

1. Пуляева В.Н. Формирование модели компетенций управленческого персонала предприятия на основе принципов сервисного менеджмента. Вестник Ассоциации вузов туризма и сервиса. 2014. № 3. Т. 8. С. 69-77.

2. Турчак В.В., Олійник Л.Г. Управління людськими ресурсами на основі моделі компетенцій. Вісник Хмельницького національного університету. 2018. № 3. T. 1. C. $75-79$.

3. McClelland D.C. Testing for Competence Rather Than for «Intelligence». American Psychologist. 1973. Vol. 28. pp. 114.

4. Spencer L.M., Spencer S.M. Competence At Work: A Model

for Superior Performance. New Jersey: John Wiley \& Sons, 1993. 388 p.

5. Кожан Т.О. Визначення видів компетенцій менеджера 3 персоналу. Соціально-трудові відносини: теорія та практика. 2013. № 2. С. 98-104.

6. Корольов Д.С. Адаптація моделі «20 граней» до оцінювання компетенцій топ-менеджменту. Науковий вісний Херсонського державного університету. Серія: Економічні науки. 2020. Вип. 37. С. 40-45.

7. Довгань Л.С., Ведута Г.А, Мохонько Л.Л. Технології управління людськими ресурсами. К.: КПІ ім. Ігоря Сікорського, 2018. 512 c.

\section{REFERENCES}

1. Pulyaeva, V.N. Formation of a model of competencies of the management staff of the enterprise on the basis of the principles of service management. Bulletin of the Association of Universities of Tourism and Service. 2014. № 3. T. 8. pp. 69 77.

2. Turchak, V.V, Oliynyk, L.G. Human resource management based on the competency model. Bulletin of Khmelnytsky National University. 2018. № 3. T. 1. pp. 75-79.

3. McClelland, D.C. Testing for Competence Rather Than for «Intelligence». American Psychologist. 1973. Vol. 28. pp. 114.

4. Spencer, L.M., Spencer, S.M. Competence At Work: A Model

for Superior Performance. New Jersey: John Wiley \& Sons, 1993. 388 p.

5. Kozhan, T.O. Defining the types of competencies of the personnel manager. Social and labor relations: theory and practice. 2013. № 2. pp. 98-104.

6. Korolov, D.S Adaptation of the "20 faces" model to the assessment of top management competencies. Scientific Spring of Kherson State University. Series: Economic Sciences. 2020. Vip. 37. pp. 40-45.

7. Dovgan, L.E, Veduta, G.A, Mokhonko, L.L Human resource management technologies. K : KPI them. Igor Sikorsky, 2018. 512 p. 